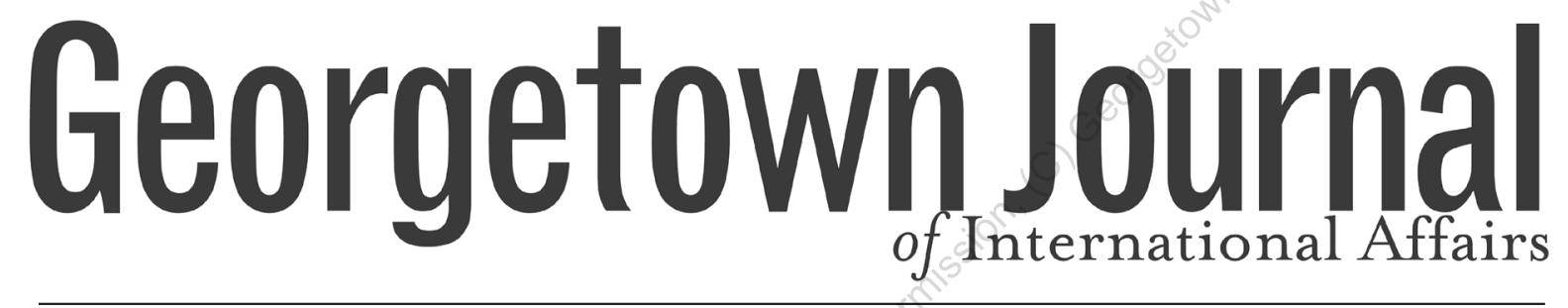

Fall 2019, Volume XX 


\section{Armed Non-State Actors and the Challenge of 21st-Century State Building}

\author{
Ariel I. Ahram
}

0 tate building has become a 21 st-century mantra, imperative for world peace and global prosperity. ${ }^{1}$ The intellectual foundation of the idea rests on a definition offered by sociologist Max Weber a century ago: a state is an entity that successfully "claims the monopoly over the legitimate use of force within a given territory." ${ }^{2}$ When states are absent, many presume the result to be a grim anarchy, with rebels, criminals, bandits, and terrorists throttling economic development and spoiling political conciliation. ${ }^{3}$ The breakdown of states spawns refugee outflows, civil wars, and mass killings that destabilize entire regions. ${ }^{4}$ The task for the international community, therefore, is to enhance state effectiveness, eliminate armed rivals, and make room for "normal" politics to take root.

This essay contends, however, that this approach is frequently misguided. States often cooperate with mercenaries, warlords, strongmen, religious or tribal leaders, ma- fias, or others who retain private armed retinues. The relationships with armed nonstate actors (ANSAs) are not contrary to political order; rather, they are fundamentally constitutive of that order. Furthermore, in many circumstances, strong states are unlikely to replace ANSAs. Instead of seeking to eliminate or marginalize ANSAs, the international community must learn to accommodate non-state actors and engage those groups that have already established themselves on the ground. This may mean accepting forms of non-state governance that are merely "good enough."5 ANSAs rarely provide a political order as robust or conducive to human flourishing as strong, capable states would. Still, engaging nonstate actors is often better than waiting in vain for a strong state to arrive.

\section{State Building and "Dirty Deals" in the Age of ANSAs}

Weber's proposition equating states with violence monopoly came at moment of profound political fragmentation. At the end of World War I, ANSAs were rampant across the former German, Hapsburg, Russian, and Ottoman imperial domains. As Weber lectured in Munich in 1919, communist forces had taken over Bavaria and were rising in other German cities. Meanwhile, bands of ex-soldiers and right-wing thugs called the Freikorps looked to avenge what they saw as the Left's betrayal of the army. The government of the new German Republic was

Ariel I. Ahram is associate professor in Virginia Tech's School of Public and International Affairs. He earned a PhD in government and an MA in Arab studies from Georgetown University. His first book, Proxy Warriors: The Rise and Fall of State-Sponsored Militias, examines why governments cooperate with armed non-state actors, such as militias, vigilantes, and warlords. He has written in some of the leading academic journals, including Survival, Terrorism and Political Violence, Studies in Conflict and Terrorism, Journal of Strategic Studies, and International Journal of Middle East Studies. Additionally, he has appeared or been quoted in the BBC Radio, CBC Radio, the Wall Street Journal, and the Washington Post's Monkey Cage blog. In 2016 he testified to the US House Foreign Relations Committee about the Islamic State's campaign of sexual violence. 
hamstrung. The nascent army and police were unable to quell the violence, while the ruling center-left Social Democrats feared a reprise of the Bolshevik coup in Russia, in which radicals pushed aside the transitional government. As the situation deteriorated, the government unleashed the Freikorps to crush the insurrection. Ultimately, this decision cost the republic dearly, demonstrating its incapacity to manage violence on its own and delegitimating it in the public eye. The idealized description of the state, as Weber knew firsthand, was missing in fact. ${ }^{6}$

Following Weber, scholars of state formation have pointed out that Europe's centralized modern states arose through a prolonged, bloody, and probably unique pathway. New states, especially the successors to empires in the developing world, were unlikely to repeat this trajectory. ${ }^{7}$ Civil wars, the most frequent and severe type of conflict since the mid-twentieth century, are indicative of how often states fail to enact the monopoly over the use of force, allowing rebels to gain control over territory. However, the international norms and laws have been slow to appreciate the discrepancy from the ideal. Mistaking the Weberian model for empirical reality, international law regards sovereignty as immutable and indivisible, even when large parts of a state's territory are outside central government control. ${ }^{8}$

But the issue is not just that states are sometimes unable to defeat armed challengers but that states often deliberately co-opt or collude with ANSAs. Studies of Africa and Latin America have long highlighted the roles of militias that collaborated with governments but remained outside the law. ${ }^{9}$ Rachel Kleinfeld, a leading scholar of violence, described these groups as parties to the "dirty deals" of "privilege violence." 10 Cross-national research showed that progovernment militias operate not only in pe- riods of war but in a variety of authoritarian and semi-democratic regime settings. ${ }^{11}$ In such circumstances, states act less as monopolist than as oligopolists in the use of force. ${ }^{12}$

As the US embarked on global counterinsurgency and counterterrorism campaigns in Afghanistan and then Iraq in the 2000s, the promises and pitfalls of such hybrid political orders became more apparent. ${ }^{13}$ The US found itself trying to build up state capacity, but often working with ANSAs of various kinds. Militias have the kind of local knowledge necessary to identify and root out guerrillas who would otherwise hide among noncombatants. They may also possess greater legitimacy in their use of force and be able to "flip" insurgents into serving the government. Locally-raised militias and their auxiliary forces were valuable in the US campaigns in Iraq $^{14}$ and Afghanistan, ${ }^{15}$ as well as the Russian war in Chechnya. ${ }^{16}$ But ANSAs also gravely endanger human rights and security. Given that they typically lack professional training, militias are especially prone to flagrant violence and ill discipline. Moreover, governments themselves maintain plausible deniability while commissioning ANSAs to do "dirty-work."17 ANSAs have been implicated in rape, masskillings, and genocide. ${ }^{18}$

History, culture, and ideology condition the way states subcontract violence to ANSAs. States do not simply pick up and drop militia allies willy-nilly. Conversely, ANSAs do not just decide to deal with the government one day, against it the next. Pakistan has been more willing to ally with radical Islamist militias than with regional separatist groups, even though Islamists often pose a greater risk of turning on the central government. The Pakistani elite views Islam as a common element of national unity, while language or regional identities are potentially disruptive and divisive. Similarly, 
Indonesia's revolutionary experience during decolonization shaped the way Jakarta would subsequently engage militias in Aceh and East Timor, defining who the government could trust with guns. ${ }^{19}$

Pro-government militias form an important but often overlooked subset of ANSAs. ${ }^{20}$ In collaborating with states, ANSAs assume a liminal position astride political, cultural, and economic seams. They take benefits generated in one sphere and sell them in another. Within the domestic arena, they are not police or soldiers, but they serve the state in coercion and their activities are technically illegal. On one hand, these ANSAs know the physical and human terrain of certain areas and enjoy a measure of respect, if not legitimacy, within it. They have a pre-existing military capacity built on local ties. States rely on ANSAs to maintain order and stability. In their home regions, ANSAs speak and work on behalf of the state while appealing for support in the indigenous language of clan, tribe, or ethnic honor. On the other hand, ANSAs act as gobetweens, speaking and acting on behalf of their local community to the state. ${ }^{21}$

State sovereignty itself is a catalyst of such arbitrage. ANSAs position themselves trilaterally as an intermediary between the nominal state, a particular constituency or group, and the international community. These type of engagements are open, but nonetheless dirty, secrets because they contradict the rhetoric of state building and belie the presumption that the international community's role is to help states reassert the monopoly over the use of force. But they have proven effective, even essential, to maintaining stability in places where states' presence is lacking. The US Army/Marine Corps Counterinsurgency Field Manuel (FM 3-24/MCWP 3-33.5) captures the abiding ambivalence in this type of engagement. It begrudgingly admits that ANSAs might be useful in the short term, only to doubledown on the imperative of state building in the long term:

If militias are outside the host-nation government's control, they can often be obstacles to ending an insurgency. Militias may become more powerful than the host-nation government, particularly at the local level. They may also fuel the insurgency and precipitate a downward spiral into a full-scale civil war. However, they can also play a constructive role and provide local security. While this can undermine the host nation's government, it can also be a building block to help build legitimacy at the local level. Militias may become insurgencies. An insurgency may also be integrated by a government and become a militia. ${ }^{22}$

An example of this type of engagement is evident in the decades-long intervention in Afghanistan. The international community insists that it aims to bring a stronger, effective, and responsive state to Afghanistan. But nearly twenty years after the US invasion, state building has been mired in corruption and violence. While development aid floods into the capital, large parts of the countryside are beyond the government's reach. Therefore, the international community subtly shifted to deal directly with the warlords who held power in the provinces. Many of these figures have received sinecures from Kabul. They were governors, parliamentarians, even ministers, but they often remained deeply involved in the illicit economy of poppy trade, smuggling, and extortion. For the US and its allies, warlords were partners in counterinsurgency. Their forces could monitor and repress Taliban activity far better than the beleaguered Afghan national army or the undermanned international forces ever could..$^{23}$ Aid and humani- 
tarian agencies, too, struck deals with local powerbrokers, often recast as "stakeholders." Although contrary to international and domestic law and organizations' own standard operating procedures, circumventing the state to reach local actors was necessary to conduct any field operations. ${ }^{24}$ Ultimately, these types of bottom-up improvisations proved essential for peace building. ${ }^{25}$

Positioned among the institutions of global governance, the central state, and local communities, ANSAs treat the arrival of military assistance, humanitarian and reconstruction aid, and diplomatic recognition as rents to be captured and redistributed. They wrest control over crucial production and export, such as the poppy trade, facing the global markets. Although arbitrary, they have an interest in maintaining local order sufficient for their own political and economic ends. ANSAs, thus, act as independent contractors offering a unique service to the international community in return for guarantees of accommodation and exemption from state control. ${ }^{26}$

\section{Conclusions}

State building, as Somalia specialist Ken Menkhaus put it, is a "wicked problem." Trying to push, prod, and punish states into asserting the monopoly over the violent use of force has unintended and often severe economic and humanitarian costs. ${ }^{27}$ As dangerous as non-state actors have been, it is states overwhelmingly that are responsible for the gravest toll on human security in the last century. ${ }^{28}$

The mantra of state building obfuscates these risks and makes alternatives harder to appreciate. Practice is increasingly outpacing theory and doctrine in this regard. Through impromptu adaptation, international actors are making their own deals with ANSAs to address problems of devel-
Trying to push, prod, and punish states into asserting the monopoly over the violent use of force has unintended and often severe economic and humanitarian costs.

opment and security at the local level by bypassing states. Working with warlords, tribal militias, gangs, and other ANSAs is no longer anathema. This comports with a more general receptiveness of hybrid political solutions. Summarizing the findings of a large-scale multicountry study of non-state forms of governance, political scientist Ulrich Schneckener recommends greater reliance on the kinds of "indigenous politics... traditional rule, clientelism, patronage, cooptation, and family- or clan-based organization" that ANSAs provide. ${ }^{29}$

The international community can do more to make such hybrid solutions more sustainable. This demands a broad assessment of the legal, economic, diplomatic, and political measures external actors can take to help ANSAs provide security and stability in the midst of state frailty. Instead of treating ANSAs as regrettable partners, more attention must be devoted to engaging them in ways that ensure comportment with basic standards of human rights and accountability. This includes consideration of the standing of ANSAs in international law and their connectivity to the global economy. ${ }^{30}$ There is likely a ceiling to what can be achieved when ANSAs cohabitate with states. A strong, effective, and unrivaled state may be the best custodian of human flourishing. But such states are the exceptions, not the norm, in the global system. ${ }^{31}$ By promoting hybrid order instead of trying to rebuild perennially weak states, the international community might be able to en- 
hance stability in areas otherwise consigned to endemic violence.

\section{Notes}

1. Francis Fukuyama, State Building: Governance and World Order in the 21st Century (Ithaca, NY: Cornell University Press, 2004); Ashraf Ghani and Clare Lockhart, Fixing Failed States: A Framework for Rebuilding a Fractured World (New York: Oxford University Press, 2009); Daron Acemoglu and James A. Robinson, Why Nations Fail: The Origins of Power, Prosperity, and Poverty (New York: Crown Books, 2012).

2. Max Weber, "Politics as Vocation," in From Max Weber: Essays in Sociology, ed. H. H. Gerth and C. Wright Mills (New York: Oxford University Press, 1958), 78 (italics in original).

3. Robert I. Rotberg, ed., When States Fail: Causes and Consequences (Princeton, NJ: Princeton University Press, 2010); Robert H. Bates, When Things Fell Apart (New York: Cambridge University Press, 2015).

4. For a critique of this view, see Stewart Patrick, "Weak States and Global Threats: Fact or Fiction?," Washington Quarterly 29, no. 2 (2006): 27-53.

5. Merilee S. Grindle, "Good Enough Governance Revisited," Development Policy Review 29, no. 1 (2011).

6. Robert Gerwarth, The Vanquished: Why the First World War Failed to End (New York: Macmillan, 2016), 120-23; Joachim Radkau, Max Weber: A Biography, trans. Patrick Camiller (Malden, MA; Polity, 2009), chapter 17.

7. Tuong Vu, "Studying the State through State Formation," World Politics 62 (2010); Anthony W. Pereira, "Armed Forces, Coercive Monopolies, and Changing Patterns of State Formation and Violence," in Armed Forces and Their Role in Politics and State Formation, ed. Diane Davis and Anthony W. Pereira (New York: Cambridge University Press, 2003); and Charles Tilly, Coercion, Capital, and European States, AD 990-1992 (Cambridge, MA: Blackwell, 1990).

8. Robert Jackson, Sovereignty: The Evolution of an Idea (Cambridge, MA: Polity, 2007).
9. On Latin America, see Mario Fumerton, "Rondas Campesinas in the Peruvian Civil War: Peasant Self-Defence Organisations in Ayacucho," Bulletin of Latin American Research 20, no. 4 (2001): 470-97; Frank Stafford and Marco Palacios, Colombia: Fragmented Land, Divided Society (New York: Oxford University Press, 2002); Adam Jones, "Parainstitutional Violence in Latin America," Latin American Politics and Society 46, no. 4 (2004): 127-48; Julie Mazzei, Death Squads or Self-Defense Forces?: How Paramilitary Groups Emerge and Challenge Democracy in Latin America (Chapel Hill: University of North Carolina Press, 2009). On Africa, see Alice Hills, "Warlords, Militia and Conflict in Contemporary Africa: A Re-examination of Terms," Small Wars \& Insurgencies 8, no. 1 (1997): 35-51; T. P. Robinson, "Twenty-First Century Warlords: Diagnosis and Treatment?," Defence Studies 1, no. 1 (2001): 121-45; William Reno, "Mafiya Troubles, Warlord Crises," in Beyond State Crisis?: Post-Colonial Africa and Post-Soviet Eurasia in Comparative Perspective, ed. Mark Beissinger and M. Crawford Young (Washington, DC: Woodrow Wilson Center Press, 2002), 105-6.

10. Rachel Kleinfeld, A Savage Order: How the World's Deadliest Countries Can Forge a Path to Security (New York: Pantheon, 2018), 294.

11. Sabine C. Carey, Neil J. Mitchell, and Will Lowe, "States, the Security Sector, and the Monopoly of Violence: A New Database on Pro-government Militias," Journal of Peace Research 50, no. 2 (2013): 249-58; Goran Peic, "Civilian Defense Forces, State Capacity, and Government Victory in Counterinsurgency Wars," Studies in Conflict \& Terrorism 37, no. 2 (2014): 162-84; Huseyn Aliyev, "No Peace, No War' Proponents? How Pro-regime Militias Affect Civil War Termination and Outcomes," Cooperation and Conflict (2018), https://doi.org/1 $0.1177 \% 2 F 0010836718766380$.

12. Douglass C. North, John Joseph Wallis, and Barry R. Weingast, "Violence and the Rise of Open-Access Orders," Journal of Democracy 20, no. 1 (2009): 55-68; Željko Branović and Sven Chojnacki, "The Logic of Security Markets: Security Governance in Failed States," Security Dialogue 42, no. 6 (2011): 553-69. 
13. Voker Boege, Anne Brown, Kevin Clements and Anna Nolan, "On Hybrid Political Orders and Emerging States: State Formation in the Context of 'Fragility," Berghof Foundation, October 2008, https://www.berghof-founda tion.org/fileadmin/redaktion/Publications /Handbook/Articles/boege_etal_handbook .pdf.

14. Stephen Biddle, Jeffrey A. Friedman, and Jacob N. Shapiro, "Testing the Surge: Why Did Violence Decline in Iraq in 2007?," International Security 37, no. 1 (2012): 7-40; Govinda Clayton and Andrew Thomson, "Civilianizing Civil Conflict: Civilian Defense Militias and the Logic of Violence in Intrastate Conflict," International Studies Quarterly 60, no. 3 (2016): 499-510.

15. Matthew P. Dearing, "A Double-Edged Sword: The People's Uprising in Ghazni, Afghanistan," Small Wars \& Insurgencies 28, no. 3 (2017): 576-608.

16. Jason Lyall, "Are Coethnics More Effective Counterinsurgents? Evidence from the Second Chechen War," American Political Science Review 104, no. 1 (2010): 1-20

17. Stanley Cohen, States of Denial: Knowing About Atrocities and Suffering (Malden, MA: Polity Press, 2001), 108-109.

18. Dara Kay Cohen and Ragnhild Nordås, "Do States Delegate Shameful Violence to Militias? Patterns of Sexual Violence in Recent Armed Conflicts," Journal of Conflict Resolution 59, no. 5 (2015): 877-98; Neil J. Mitchell, Sabine C. Carey, and Christopher K. Butler, "The Impact of Pro-government Militias on Human Rights Violations," International Interactions 40, no. 5 (2014): 812-36; Clionadh Raleigh, "Violence against Civilians: A Disaggregated Analysis," International Interactions 38, no. 4 (2012): 462-81; Ore Koren, "Means to an End: Pro-government Militias as a Predictive Indicator of Strategic Mass Killing," Conflict Management and Peace Science 34, no. 5 (2017): 461-84.

19. Ariel I. Ahram, "Pro-government Militias and the Repertoires of Illicit State Violence," Studies in Conflict \& Terrorism 39, no. 3 (2015): 207-226; Paul Staniland, "Militias, Ideol- ogy, and the State," Journal of Conflict Resolution 59, no. 5 (2015): 770-93.

20. Peter G. Thompson, Armed Groups: The 21st Century Threat (Lanham, MD: Rowman \& Littlefield, 2014), 89-91.

21. Ariel I. Ahram and Charles King, "The Warlord as Arbitrageur," Theory and Society 41, no. 2 (2012): 169-86; Kimberly Marten, "Warlords and Governance," in The Transnational Governance of Violence and Crime: Nonstate Actors in Security, ed. Anja Jakobi and K. Wolf (New York: Springer, 2013), 23-39.

22. FM 3-24/MCWP 3-33.5 Insurgencies and Countering Insurgencies (Revised June 2014) Section 5-47, 48, http://www.apd.army.mil/epubs /DR_pubs/DR_a/pdf/web/fm3_24.pdf.

23. Dipali Mukhopadhyay, Warlords, Strongman Governors, and the State in Afghanistan (New York: Cambridge University Press, 2014); Jennifer Brick Murtazashvili, Informal Order and the State in Afghanistan (New York: Cambridge University Press, 2016); Romain Malejacq, Warlord Survival: The Delusion of State Building in Afghanistan (Ithaca, NY: Cornell University Press, forthcoming).

24. Antonio Donini, "Afghanistan: Back to the Future," in The Golden Fleece: Manipulation and Independence in Humanitarian Action, ed. Antonio Donini, (Sterling, VA: Kumarian Press, 2012), 67-85; Fiona Terry, "The International Committee of the Red Cross in Afghanistan: Reasserting the Neutrality of Humanitarian Action," International Review of the Red Cross 93, no. 881 (2011): 173-88; Annyssa Bellal, Gilles Giacca, and Stuart Casey-Maslen, "International Law and Armed Non-state Actors in Afghanistan," International Review of the Red Cross 93, no. 881 (2011): 47-79.

25. Susanna P. Campbell, Global Governance and Local Peace: Accountability and Performance in International Peacebuilding (New York: Cambridge University Press, 2018).

26. Paul B. Rich, "Warlords, State Fragmentation and the Dilemma of Humanitarian Intervention," Small Wars \& Insurgencies 10, no. 1 (1999): 78-96.

27. Kenneth Menkhaus, "State Fragility as a Wicked Problem,” Prism, 1, no. 2 (2009). 
28. Barbara Harff, "No Lessons Learned from the Holocaust? Assessing Risks of Genocide and Political Mass Murder since 1955," American Political Science Review 97, no. 1 (2003): 5773.

29. Ulrich Schneckener, "State Building or New Modes of Governance?," in Governance without a State?: Policies and Politics in Areas of Limited Statehood, ed. Thomas Risse (New York: Columbia University Press, 2011), 257. See also Jennifer Murtazashvili, "A Tired Cliché: Why
We Should Stop Worrying about Ungoverned Spaces and Embrace Self-Governance," Journal of International Affairs 71, no. 2 (2018): 11-29.

30. Katharine Fortin, The Accountability of Armed Groups under Human Rights Law (New York: Oxford University Press, 2017).

31. Arjon Chowdruy, The Myth of International Order: Why Weak States Persist and Alternatives to the State Fade Away (New York: Oxford University Press, 2018). 